UDC 621.695: 622.27

A.V.Sladkowski ${ }^{1}$, Dr. Sc. (Tech.), Prof.,
orcid.org/0000-0002-1041-4309,
Y. O. Kyrychenko ${ }^{2}$, Dr. Sc. (Tech.), Prof.,
orcid.org/0000-0002-3914-2810,
P. I. Kogut ${ }^{3}$, Dr. Sc. (Phys.-Math.), Prof.,
orcid.org/0000-0003-1593-0510,
V.I. Samusya ${ }^{2}$, Dr. Sc. (Tech.), Prof.,
orcid.org/0000-0002-6073-9558,
D. L. Kolosov ${ }^{2}$, Dr. Sc. (Tech.), Assoc. Prof.,
orcid.org/0000-0003-0585-5908
DOI: $10.29202 /$ nvngu/2019-2/6

1 - Silesian University of Technology, Katowice, Poland, e-mail: aleksander.sladkowski@polsl.pl

2 - Dnipro University of Technology, Dnipro, Ukraine, e-mail: vsamusya@gmail.com; evolyuta@gmail.com

3 - Oles Honchar Dnipro National University, Dnipro, Ukraine, e-mail: p.kogut@i.ua

\title{
INNOVATIVE DESIGNS OF PUMPING DEEP-WATER HYDROLIFTS BASED ON PROGRESSIVE MULTIPHASE NON-EQUILIBRIUM MODELS
}

Purpose. Development of methodological support for a unique method of a pumping deep-water hydrolift (PDH) for transporting multiphase flows with a solid fraction and innovative pumping systems for its implementation in complex conditions of great depths.

Methodology. Theoretical studies of a mechanism of multiphase flows in a flow section of a hydrolift transport pipeline and designs of a pumping unit that transports heavy hydro mixture with an abrasive solid fraction to build an adequate model of a pumping deep-water hydrolift of gasified liquids with high gas content. The method is based on a logical structure of multiphase flow studies under conditions of large pressure gradients and a new approach to the calculation of powerful hydrolifts that pump compressible and incompressible non-equilibrium heterogeneous mixtures. Depending on the size of a desorption flow and the depth of a hydrolift, a rational amount of pumping units and their location are determined. Flow and energy parameters of a process of transportation of a hydro mixture using mathematics and software for a method of hydrolifting are calculated.

Findings. An experimental technology for transporting heavy abrasive rock masses in oceanic areas with high gas content in sea water is suggested. This technology is the combination of an innovative method of a pumping hydrolift of solid material as part of gasified liquids and the original design of a pumping unit and also is distinguished by improved performance characteristics. A new deterministic model of a non-equilibrium multiphase flow in a pressure pipeline of considerable length and a simulation software complex is developed.

Originality. A unique PDH that transports heterogeneous mixtures, created on progressive non-equilibrium multiphase models considering the processes of desorption mass transfers caused by significant pressure gradients is developed.

Practical value. Innovative designs of pumping units are suggested and patented, which prevent overmilling of solid particles by eliminating the interaction of a pump impeller with transported material.

Keywords: pump, pipeline, impeller, hydrotransport, phase, mathematical model, heterogeneous mixtures, design

Modern requirements of safety, performance and energy efficiency stimulate scientific and technological progress in the field of creation $[1,2]$ and engineering support of operation $[3,4]$ of machines, their equipment $[5,6]$ and mechanisms $[7,8]$ for mining $[9,10]$, transportation [11, 12] and mechanical engineering [13, 14].

At the present time, a new branch of mining is being rapidly developed - deep sea mining. Leading global companies show primary interest for a development of large deep-water polymetallic ore deposits. The main technological operation is transportation of extracted raw materials to the surface. As a result of analysis of main efficiency indicators of a hydrotransport system (availability coefficient, efficiency coefficient, solid granulometric composition, degree of equipment functionality, deposit development specifics, adaptability to operating conditions), it is shown that the pump version of a hydrolift in a wide range of depth and productivity changes is the most promising.

(c) Sladkowski A. V., Kyrychenko Y. O., Kogut P. I., Samusya V. I., Kolosov D. L., 2019
The results of geological exploration showed that significant deposits of solid minerals that pose industrial interest were found in the Pacific and Indian oceans. In addition, there are vast areas of volcanic nature at great depths, characterized by abnormally high gas content in sea water. Vast experience of working with various pumps in mining and oil and gas industries has been accumulated. In the oil and gas industry, multiphase pumps are used to pump oil and gas mixtures [15]. Slurry pumps are used for hydrotransport of mixtures of liquids and solid materials in horizontal pipelines [16] in the development of deep-water solid mineral deposits [17]. A significant part of scientific publications is dedicated to the design and study of dynamic processes in airlift systems [18, 19]. Nevertheless, the analysis of the results of studies of pumping deep-water lifts for transporting hydro mixtures in vertical pipelines showed a lack of publications in open sources in this field during the past 5 years. The exception is only one paper [20].

Problem statement. The problem of deep-water pumping hydrotransport systems is high energy intensity 
and low reliability of pumping deep-water hydrolift in complex conditions of great depths.

Unsolved aspects of the problem consist in decreasing the efficiency of pumping deep-water hydrolift with increasing depths of development and during transportation of highly concentrated abrasive slurries.

This work is relevant, since it is devoted to further development of a pumping variant of a hydrolift, which has a tendency of improvement through increasing the reliability of installations by developing progressive designs that prevent the interaction of solid particles with the blades of impellers of pumping units. In addition, the suggested approach allows increasing the efficiency of a hydrolifting process in the conditions of oceanic areas with high gas content.

The objective of the paper is to develop methodological support for a unique method of pumping deep-water hydrolift for transporting multiphase flows with a solid fraction and innovative pumping systems for its implementation in complex conditions of great depths.

When modeling the installation, it is expedient to conditionally split the transport pipeline into two sections. Two-phase hydro mixture (liquid and solid particles) moves in the lower part. A 3-phase mixture of a bubble structure (liquid, solid particles and gas) moves in the upper part of a pipeline, due to the intensity of desorption. Improving the efficiency of the transportation process of solid material is due to natural additional airlift effect. In addition, the desorption flow significantly changes static and dynamic properties of gasified liquids.

A deep-water mining complex, equipped with a pumping hydrolift is shown in Fig. 1.

Considering these features, the following mathematical model of a PDH that is self-adjusting to the properties of a transporting medium (2 and 3-phase mixtures) is suggested. The first step of the experimental innovative technology is development of mathematical software for a method of pumping deep-water hydrolift and structures of its implementation. The ideology of mathematical software of the method is based on use of separate models of multi-phase unsteady flow from a con-

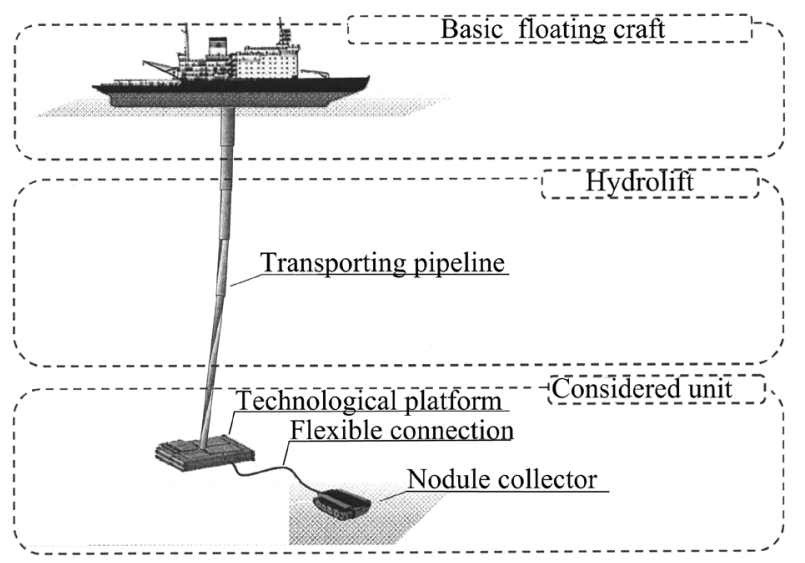

Fig.1. Deep-water mining complex, equipped with a pumping hydrolift [21] tinual point of view. The transported mixture consists of various interacting, interpenetrating continuous phases, characterized by their own densities and velocities. In addition, neglect the change in flow parameters in a cross-section of a pipeline, rotation and collision of particles with each other, the distortion of flow lines of liquid and the increase in turbulent pulsations. At the same time, solid particles are the same shape, diameter and surface condition.

The lower section of a pumping pipeline that transports a two-phase mixture is described via a system of two equations of motion of an unsteady equilibrium process and two equations of continuity

$$
\begin{aligned}
& \frac{\left(1-C_{1}\right)}{\rho_{0}} \frac{\partial p}{\partial x}-\frac{C_{1} k_{1}}{2}\left(\frac{\partial v_{1}}{\partial t}+v_{1} \frac{\partial v_{1}}{\partial x}\right)++\left(1+\frac{C_{1} k_{1}}{2}\right)\left(\frac{\partial v_{0}}{\partial t}+v_{0} \frac{\partial v_{0}}{\partial x}\right)= \\
&=-\frac{3}{8}\left[\frac{C_{1} C_{x_{1}}}{R_{1}}\left|v_{0}-v_{1}\right|\left(v_{0}-v_{1}\right)\right]- \\
&-\frac{\lambda p}{2 D} \frac{\rho_{p}}{\rho_{0}}\left|v_{p}\right| v_{p}-\left(1-C_{1}\right) g \sin \alpha ; \\
& \frac{1}{\rho_{0}} \frac{\partial p}{\partial x}-\left(1+\frac{k_{1}}{2}\right)\left(\frac{\partial v_{0}}{\partial t}+v_{0} \frac{\partial v_{0}}{\partial x}\right)+ \\
&+\left(\frac{\rho_{1}}{\rho_{0}}+\frac{k_{1}}{2}\right)\left(\frac{\partial v_{1}}{\partial t}+v_{1} \frac{\partial v_{1}}{\partial x}\right)= \\
&= \frac{3}{8} \frac{C_{x_{1}}}{R_{1}}\left|v_{0}-v_{1}\right|\left(v_{0}-v_{1}\right)-\frac{\rho_{1}}{\rho_{0}} g \sin \alpha ; \\
& \rho_{0} a_{0}^{2}\left(1-C_{1}\right) \frac{\partial v_{0}}{\partial x}-\rho_{0} a_{0}^{2}\left(\frac{\partial C_{1}}{\partial t}+v_{0} \frac{\partial C_{1}}{\partial x}\right)+ \\
&+\left(1-C_{1}\right)\left(\frac{\partial p}{\partial t}+v_{0} \frac{\partial p}{\partial x}\right)=0 ; \\
& \rho_{1} a_{1}^{2} C_{1} \frac{\partial v_{1}}{\partial x}+\rho_{1} a_{1}^{2}\left(\frac{\partial C_{1}}{\partial t}+v_{1} \frac{\partial C_{1}}{\partial x}\right)+C_{1}\left(\frac{\partial p}{\partial t}+v_{1} \frac{\partial p}{\partial x}\right)=0 .
\end{aligned}
$$

The upper section of the pumping pipeline is described by a system of three equations of motion of an unsteady non-equilibrium process, considering the desorption mass transfer and three equations of continuity

$$
\begin{gathered}
\varphi_{0}=\frac{\left(1-C_{1}-C_{2}\right)}{\rho_{0}} \frac{\partial p}{\partial x}-\frac{C_{1} k_{1}}{2}\left(\frac{\partial v_{1}}{\partial t}+v_{1} \frac{\partial v_{1}}{\partial x}\right)- \\
-\frac{C_{2} k_{2}}{2}\left(\frac{\partial v_{2}}{\partial t}+v_{2} \frac{\partial v_{2}}{\partial x}\right)+ \\
+\left(1+\frac{C_{1} k_{1}}{2}+\frac{C_{2} k_{2}}{2}\right)\left(\frac{\partial v_{0}}{\partial t}+v_{0} \frac{\partial v_{0}}{\partial x}\right) ; \\
\varphi_{1}=\frac{1}{\rho_{0}} \frac{\partial p}{\partial x}-\left(1+\frac{k_{1}}{2}\right)\left(\frac{\partial v_{0}}{\partial t}+v_{0} \frac{\partial v_{0}}{\partial x}\right)+ \\
+\left(\frac{\rho_{1}}{\rho_{0}}+\frac{k_{1}}{2}\right)\left(\frac{\partial v_{1}}{\partial t}+v_{1} \frac{\partial v_{1}}{\partial x}\right) ;
\end{gathered}
$$




$$
\begin{gathered}
\varphi_{2}=\frac{1}{\rho_{0}} \frac{\partial p}{\partial x}-\left(1+\frac{k_{2}}{2}\right)\left(\frac{\partial v_{0}}{\partial t}+v_{0} \frac{\partial v_{0}}{\partial x}\right)+ \\
+\left(\frac{\rho_{2}}{\rho_{0}}+\frac{k_{2}}{2}\right)\left(\frac{\partial v_{2}}{\partial t}+v_{2} \frac{\partial v_{2}}{\partial x}\right) \\
G=\left(1-C_{1}-C_{2}\right)\left(\frac{\partial p}{\partial t}+v_{0} \frac{\partial p}{\partial x}\right)-\rho_{0} a_{0}^{2}\left(\frac{\partial C_{1}}{\partial t}+v_{0} \frac{\partial C_{1}}{\partial x}\right)- \\
-\rho_{0} a_{0}^{2}\left(\frac{\partial C_{2}}{\partial t}+v_{0} \frac{\partial C_{2}}{\partial x}\right)+\rho_{0} a_{0}^{2}\left(1-C_{1}-C_{2}\right) \frac{\partial v_{0}}{\partial x} \\
\rho_{1} a_{1}^{2} C_{1} \frac{\partial v_{1}}{\partial x}+\rho_{1} a_{1}^{2}\left(\frac{\partial C_{1}}{\partial t}+v_{1} \frac{\partial C_{1}}{\partial x}\right)+ \\
+C_{1}\left(\frac{\partial p}{\partial t}+v_{1} \frac{\partial p}{\partial x}\right)=0 \\
-G=\rho_{2} a_{2}^{2} C_{2} \frac{\partial v_{2}}{\partial x}+\rho_{2} a_{2}^{2}\left(\frac{\partial C_{2}}{\partial t}+v_{2} \frac{\partial C_{2}}{\partial x}\right)+ \\
+C_{2}\left(\frac{\partial p}{\partial t}+v_{2} \frac{\partial p}{\partial x}\right),
\end{gathered}
$$

where

$$
\begin{gathered}
\varphi_{0}=-\frac{\lambda_{m}}{2 D} \frac{\rho_{m}}{\rho_{0}}\left|\mathrm{v}_{m}\right| \mathrm{v}_{m}+ \\
+\frac{3}{8}\left[\frac{C_{1} C_{x_{1}}}{R_{1}}\left|\mathrm{v}_{0}-\mathrm{v}_{1}\right|\left(\mathrm{v}_{0}-\mathrm{v}_{1}\right)+\frac{C_{2} C_{x_{2}}}{R_{2}}\left|\mathrm{v}_{0}-\mathrm{v}_{2}\right|\left(\mathrm{v}_{0}-\mathrm{v}_{2}\right)\right]- \\
-\left(1-C_{1}-C_{2}\right) g \sin \alpha ; \\
\varphi_{1}=\frac{3}{8} \frac{C_{x_{1}}}{R_{1}}\left|\mathrm{v}_{0}-\mathrm{v}_{1}\right|\left(\mathrm{v}_{0}-\mathrm{v}_{1}\right)-\frac{\rho_{1}}{\rho_{0}} g \sin \alpha ; \\
\varphi_{2}=\frac{3}{8} \frac{C_{x_{2}}}{R_{2}}\left|\mathrm{v}_{0}-\mathrm{v}_{2}\right|\left(\mathrm{v}_{0}-\mathrm{v}_{2}\right)-\frac{\rho_{2}}{\rho_{0}} g \sin \alpha ; \\
\frac{1}{a_{1}^{2}}=\frac{\rho_{1}}{K_{1}}+\frac{\rho_{1}}{F}\left(\frac{\partial F}{\partial p}\right) ; \\
\frac{\rho_{2}}{a_{2}^{2}}+\frac{\rho_{2}}{F}\left(\frac{\partial F}{\partial p}\right) ; \quad \frac{1}{a_{0}^{2}}=\frac{1}{a_{f}^{2}}+\frac{\rho_{0}}{F}\left(\frac{\partial F}{\partial p}\right) ; \\
a_{f}^{2}=\frac{K_{f}}{\rho_{0}} ; \quad K_{1}=\frac{E_{1}}{3\left(1-2 v_{1}\right)} ; \\
\frac{1}{K_{2}}=\frac{1}{\rho_{2}}\left(\frac{\partial \rho_{2}}{\partial p}\right)=\frac{1}{\rho_{2} a_{b}^{2}} ; \\
\rho_{m}=\rho_{0}^{*}+\rho_{1}^{*}+\rho_{2}^{*}=\left(1-C_{1}-C_{2}\right) \rho_{0}+C_{1} \rho_{1}+C_{2} \rho_{2} ; \\
v_{m}=\frac{1}{\rho_{m}}\left(\rho_{0}^{*} \mathrm{v}_{0}+\rho_{1}^{*} \mathrm{v}_{1}+\rho_{2}^{*} \mathrm{v}_{2}\right)
\end{gathered}
$$

$F-$ is the flow area of a pipeline, which is considered deformable under the action of internal pressure forces, $F=\frac{\pi D^{2}}{4} ; \quad \rho_{0}^{*}=\rho_{0}\left(1-C_{1}-C_{2}\right) ; \quad \rho_{1}^{*}=C_{1} \rho ; \quad \rho_{2}^{*}=C_{2} \rho_{2} ;$ $a_{f}-$ velocity of sound in pure unbounded fluid; $K_{f}-$ bulk modulus of elasticity of fluid; $a_{0}$ - velocity of propagation of small perturbations in a pipeline with pliable walls for clean fluid; $\frac{\partial F}{\partial p}$ - pliability of a cross section of a pipeline in relation to internal pressure; $K_{1}$ - bulk compression modulus for solids; $E_{1}$ and $v_{1}$ - Young's modulus and Poisson's ratio of material of solid particles; $K_{2}$ - bulk compression modulus of a gaseous phase; $a_{b}$ - velocity of sound in a gas bubble; $G$ - specific desorption flow; $v_{0}, v_{1}, v_{2}-$ velocities of liquid, solid and gaseous phases; $\rho_{0}, \rho_{1}, \rho_{2}-$ true densities of carrier liquid, solids and gas in gas bubbles; $C_{1}, C_{2}$ - volume fraction of solid and gaseous matter in the mixture; $C_{0}=$ $=1-C_{1}-C_{2}-$ volume fraction of carrier liquid; $p-$ pressure; $x$ - vertical coordinate; $t-$ time; $C_{x_{1}}, C_{x_{2}}-$ frontal resistance coefficient of a solid particle or gas bubble; $\lambda_{p}, \lambda_{m}-$ Darcy friction factor of pulp or threephase mixture; $D$ - pipeline diameter; $g$ - free fall acceleration; $\alpha$-pipeline inclination angle; $R_{1}, R_{2}$-radius of a solid particle or gas bubble; $k_{1}, k_{2}$ - coefficient of influence of phase element on non-sphericity and concentration. Indices denote: 0 - liquid, 1 - solid particle, $2-$ gas bubbles, $p$ - pulp, $m-$ mixture.

Equations (1-10) are added with corresponding initial and boundary conditions that depend on the size of gas content of sea environment in a specific region of the World Ocean. The authors clearly understand that the continuity equations $(8-10)$ strictly describe the process of mass transfer in a case of steam-water rather than gaswater mixture, as in our case with the use of Henry's law [20]. However, at this stage of research, this assumption may be acceptable. Universality of the mathematical model is that in a case of neglecting the gas phase with $C_{2}=0$ in equations $(5,8,10)$, the resulting system of equations automatically turns into (1-4). In other words, the developed model describes processes in both the lower and upper sections of a transport pipeline that transports both the two-phase and three-phase mixtures. In addition, the equations are applicable for an arbitrary orientation of a transport pipeline, since they allow varying its angle of inclination. For the majority of operating modes, the shape of a transport pipeline is either vertical or inclined with a variable curvature, and the productivity by solid material of a pumping deepwater hydrolift significantly depends on the angle of inclination of a transport pipeline. The efficiency of the model lies in a fact that only one type of equation is used; this is essential for numerical integration of differential equations for solving multidimensional problems. The developed model is integrated into an intelligent iterative calculation procedure for numerical implementation of the suggested approach.

Methodological support of the suggested experimental technology includes mathematical and software parts. The enlarged structure of the research has a following form.

1. Based on results of geological exploration, a promising ocean region with high gas content in sea water is determined for extraction of solid minerals.

2. After the complex is installed in the selected area, a transport pipeline is conditionally split into two sections depending on the volume gas content. 
3. A two-phase model is used for the lower section of a transport pipeline in the area of significant pressure with insignificant gas content to determine flow rate and energy parameters of a flow.

4. For the upper part of a transport pipeline with decreasing pressure and increasing gas content for a bubble structure of a mixture flow, a three-phase model is used in calculations.

5. Types of pumps, their location and their rational amount are determined depending on a depth of a hydrolift.

6. Software modules for implementation of two- and three-phase models describing the lower and upper sections of a transport pipeline are developed.

7. A simulation complex of pumping deep-water hydrolift is discovered in a final stage of designing. It combines the developed software modules and is prepared for design investigation.

Given the significant increase in the dimension of problems associated with numerical methods for integrating differential equations, it is advisable to use the software library for numerical computations in applied mathematics and science (GNU Scientific Library), which significantly expands the set of mathematical possibilities.

Improvement of the pumping hydrolift is in reducing the energy intensity of transporting the material using the airlift effect and increasing the reliability and durability of installations by developing special designs that eliminate interaction of solid material with blades of impellers of pumping units.

Hydrotransport system operates as shown in Fig. 2.

The control unit 7 starts the pump 1 filled with seawater that starts pumping out the water concentrated in the accumulator 4 . When pumping the water from the accumulator, a hydro mixture stream containing minerals begins to flow into it under the action of static pressure. When the flow formed by the pressure pipeline pump 3 passes through the accumulator, an ejection effect occurs due to the tip 12. This effect ensures that the seawater concentrated in the accumulator 4 flows together with the high-pressure flow formed by the pump.

When the hydro mixture flow gets from the part of the suction pipe 2 , that is connected with an ocean ba$\sin$, into the accumulator, the velocity of the hydro mixture decreases. Thus, a process of continuous sedimentation of solid particles from the suction pipe takes place in the accumulator under the action of gravity. During the sedimentation process, solid material enters the bottom of accumulator, where it enters an ejection zone, and is transported as part of the flow of the pressure pipeline section. The design of the tip provides the reduction of the area of its cross-section in the direction of a hydro mixture flow. This prevents the high-pressure flow from the section of the pumping pipe getting into the section of the suction pipe through the accumulator. Thus, it is possible to continuously lift the raw mineral materials within the hydro mixtures, preventing the interaction of solid particles with the blades of operating elements of the pump.

For the case of ensuring high productivity of hydrotransport, a screw feeder is provided in the accumulator.
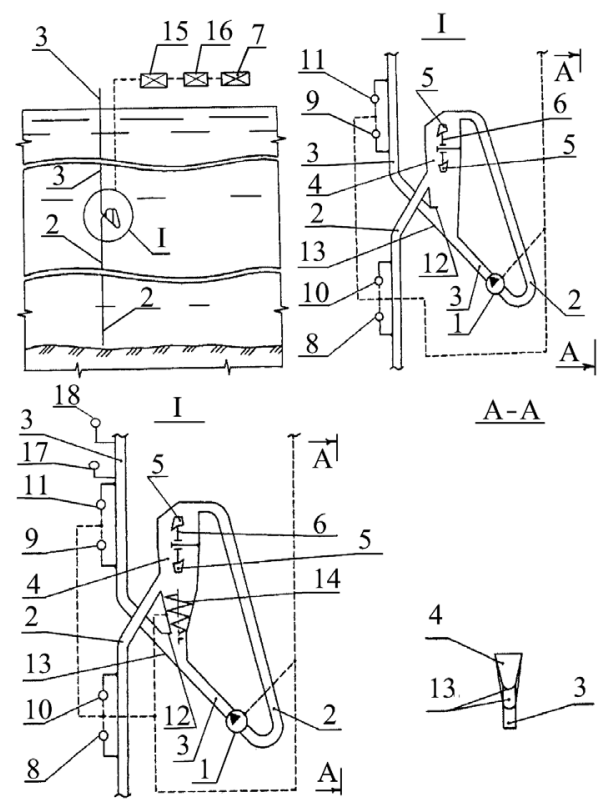

\section{Fig. 2. Hydrotransport system}

The location levels of attachment zones of parts of a suction pipe, connected with the ocean basin and the pump, to the accumulator are above the level of the screw feeder 14. In this variant of a system, the control unit starts the screw feeder after the pump reaches its performance parameters. The screw feeder ensures the guaranteed transfer of the entire volume of solid material into the flow of the pressure pipeline.

The design of a tip described above also ensures the efficient integration of the pressure pipe flow after solid particles are integrated.

The trajectory of a flow of a suction pipe through the blades 5 of the impeller 6 ensures its rotation, what contributes to the sedimentation of raw mineral materials, and also prevents the agglomeration of solid material in the accumulator and clogging.

Avoiding the clogging of a hydrotransport system is also achieved as a result of washing the entire area of an accumulator bottom - the inclined trough 13 , with a flow of the discharge pipe.

After starting the pump, the control unit, using the sensor for determining the flow rate of the liquid 8 and the consistometer 10 , controls the mass flow rate of the solid material in a flow of a suction pipe before removing solid particles from its composition. Using the sensor for determining the flow rate of liquid 9 and consistometer 11 , the control unit also monitors the mass flow rate of raw mineral materials in a flow of the pressure pipeline after the inclusion of solid particles removed from a hydro mixture flow of a suction pipe. Next, the controlled values are compared and their compliance is achieved by adjusting the pump flow rate.

If it is necessary to increase the mass flow rate of the solid component in a hydro mixture flow of the pressure pipe after solid particles that are included in its composition, are removed from the hydro mixture of the suction pipe, the control unit increases the pump flow rate. 
Immediately before the system stops, the control unit stops the pump and the screw feeder.

Restarting hydrotransport system is performed according to the above algorithm. It is the combination of a unique method of hydrolifting and an innovative pumping unit, including a number of original designs, which ensures the reduction of the energy intensity of the process of transporting heavy abrasive slurries, simultaneously with increasing the reliability of the system, and is know-how of this technology. In this context, improvements have been made to the previously known methods and installations for hydrolifting of a two-phase hydro mixture [20]. In order to increase the efficiency of transportation of a three-phase soil-liquid-air mixtures in the upper section of a transport pipeline, constructive and functional changes have been suggested. A threephase mixture flow control unit 15 , an intelligent hydrolift process control unit 16 in the entire transport pipeline (upper and lower sections), a three-phase mixture flow sensor 17, a three-phase consistency sensor 18 are additionally included. In addition, in the upper section of the transport pipeline, the types of pumps 1 are changed. A number of features of installation are contained within the corresponding know-how documentation for this design.

\section{Conclusions.}

1. The suggested pumping deep-water hydrolift is a unique mining machine for the conditions of oceanic areas with high gas content in seawater, and characterized by increased transportation efficiency of heavy abrasive media due to the additional "free" airlift effect, and having a high probability of technical implementation in complex conditions of great depths.

2. A new approach to calculation of unconventional pumping hydrolift units which pump compressible and incompressible hydro mixtures in long pipelines of various inclinations is suggested, which allow investigating the parameters of two- and three-phase flows effectively, quickly and efficiently within a single mathematical apparatus.

3. A mathematical and software modeling complex and a method for calculating an unconventional pumping deep-water hydrolift using the characteristic ratios of hyperbolic differential equations describing the dynamics of multi-phase flows with the most complete account of forces of inter-phase interaction within the bubble structure of the mixture flow have been developed.

4. An increase in reliability of the developed hydrotransport systems of raw mineral materials is achieved due to the guaranteed prevention of a possibility of clogging of structural elements of an intelligent hydrolift system by solid material and, as a result, a significant improvement in operating conditions in high-performance pumps with high efficiency.

5. The implementation of a method of transportation of solid material in a composition of gasified suspended liquid allows a less energy-consuming mode of hydrolifting of heavy slurries due to the airlift effect and reduces the wear of a pipeline. At the same time, eliminating the interaction of abrasive solid material with impellers increases the reliability of pumping units.

Prospects. At the next stage of development of this technology, systematic modeling of design and operational parameters of a deep-water hydrotransport system is envisaged in wide ranges of changes of its productivity and depths of field development in order to determine rational operating modes.

\section{References.}

1. Bondarenko, V.I., Samusya, V.I. and Smolanov, S. N., 2005. Mobile lifting units for wrecking works in pit shafts. Gornyi Zhurnal [online], 5, pp. 99-100. Available at: <https://www.researchgate.net/publication/293115005_Mobile_lifting_units_for_wrecking works_in_pit_shafts> [Accessed 11 July $201 \overline{7}]$.

2. Taran, I.A., 2012. Laws of power transmission on branches of double-split hydrostatic mechanical transmissions. Naukovyi Visnyk Natsionalnoho Hirnychoho Universytetu, 2, pp. 69-75.

3. Bazhenov, V.A., Gulyar, A.I., Piskunov, S.O. and Shkryl, A.A., 2008. Gas turbine blade service life assessment with account of fracture stage. Strength of Materials [online], 40(5), pp. 518-524. DOI: 10.1007/s11223008-9064-5.

4. Kolosov, D., Bilous, O., Tantsura, H. and Onyshchenko, S., 2018. Stress-strain state of a flat tractive-bearing element of a lifting and transporting machine at operational changes of its parameters. Solid State Phenomena, 277, pp. 188-201. DOI: 10.4028/www.scientific.net/SSP.277.188.

5. Pukach, P. Ya., Kuzio, I. V., Nytrebych, Z.M. and Il'kiv, V.S., 2018. Asymptotic method for investigating resonant regimes of nonlinear bending vibrations of elastic shaft. Naukovyi Visnyk Natsionalnoho Hirnychoho Universytetu, 1, pp. 68-73. DOI: 10.29202/nvngu/2018-1/9.

6. Bazhenov, V.A., Gulyar, A. I., Piskunov, S. O. and Andrievskii, V.P., 2013. Design life assessment of the blade root of a gas turbine unit under thermomechanical loading. Strength of Materials, 45(3), pp. 329-339. DOI: $10.1007 / \mathrm{s} 11223-013-9463-0$.

7. Filimonikhin, G. and Olijnichenko, L., 2015. Investigation of the possibility of balancing aerodynamic imbalance of the impeller of the axial fan by correction of masses. Eastern-European Journal of Enterprise Technologies, 5(7(77)), pp. 30-35. DOI: 10.15587/17294061.2015.51195.

8. Filimonikhin, G., Filimonikhina, I., Yakymenko, M. and Yakimenko, S., 2017. Application of the empirical criterion for the occurrence of auto-balancing for axisymmetric rotor on two isotropic elastic supports. Eastern-European Journal of Enterprise Technologies, 2(7(86)), pp. 51-58. DOI: 10.15587/1729-4061.2017.96622.

9. Pivnyak, G., Dychkovskyi, R., Bobyliov, O., Cabana, C. E. and Smoliński, A., 2018. Mathematical and geomechanical model in physical and chemical processes of underground coal gasification. Solid State Phenomena, 277, pp. 1-16. DOI: 10.4028/www.scientific.net/SSP.277.1.

10. Loveikin, V.S. and Romasevych, Yu. O., 2017. Dynamic optimization of a mine winder acceleration mode. Naukovyi Visnyk Natsionalnoho Hinychoho Universytetu, 4, pp. 55-61. 
11. Shpachuk, V., Chuprynin, A., Suprun, T. and Garbuz, A., 2018. A multifactor analysis of the rail transport car that passes over a joint unevenness with respect to the phases ot its motion. EasternEuropean Journal of Enterprise Technologies, 1(7(91)), pp. 55-61. DOI: 10.15587/1729-4061.2018.121584.

12. Taran, I. and Bondarenko, A., 2017. Conceptual approach to select parameters of hydrostatic and mechanical transmissions for wheel tractors designed for agricultural operations. Archives of transport, 41(1), pp. 89-100. DOI: 10.5604/01.3001.0009.7389.

13. Bazhenov, V.A., Gulyar, A.I. and Piskunov, S.O., 2005. Modeling creep and continuous fracture process zones in spatial prismatic bodies. International Applied Mechanics [online], 41(9), pp. 1016-1030. DOI: 10.1007/ s10778-006-0009-z.

14. Kolosov, D., Dolgov, O. and Kolosov, A., 2014. Analytical determination of stress-strain state of rope caused by the transmission of the drive drum traction. Progressive Technologies of Coal, Coalbed Methane, and Ores Mining, pp. 499-504.

15. Hanafizadeh, P., Raffiee, A.H. and Saidi, M.H., 2014. Experimental investigation of characteristic curve for gas-lift pump. Journal of Petroleum Science and Engineering, 116,pp. 19-27. DOI:10.1016/j.petrol.2014.02.011. 16. Protsiv, V., Ziborov, K. and Fedoriachenko, S., 2015. Test load envelope of semi - Premium O\&G pipe coupling with bayonet locks. New Developments in Mining Engineering 2015: Theoretical and Practical Solutions of Mineral Resources Mining, pp. 261-264.

17. Bondarenko, A.A., 2018. Theoretical bases of pulp suction process in the shallow dredge underwater face. Naukovyi Visnyk Natsionalnoho Hirnychoho Universytetu, 3, pp. 22-29. DOI: 10.29202/nvngu/2018-3/4.

18. Hu, D., Kang, Y., Tang, C. and Wang, X., 2015. Modeling and analysis of airlift system operating in three-phase flow. China Ocean Engineering, 29(1), pp. 121-132. DOI:10.1007/s13344-015-0009-Z.

19. Fan, W., Chen, J., Pan, Y., Huang, H., Chen, C.A. and Chen, Y., 2013. Experimental study on the performance of an air-lift pump for artificial upwelling. Ocean Engineering, 59, pp. 47-57. DOI: 10.1016/j.oceaneng.2012.11.014.

20. Kyrychenko, E.A., Goman, O. G., Kirichenko, V. E. and Evteev, V.V., 2014. Fundamentals of designing hydraulic handling systems for polymetallic ores. Nikopol: FOP Feldman O. O.

21. Kyrychenko, V., Kyrychenko, E., Samusya, V. and Antonenko, A., 2014. Concerning CAE systems development of hydraulic hoists within ship mining complexes. Progressive Technologies of Coal, Coalbed Methane, and Ores Mining, pp. 451-456.

\section{Інноваційні конструкції насосних глибоководних гідропідйомів на базі прогресивних багатофазних нерівноважних моделей}

О. В. Сладковськи ${ }^{1}$, С. О. Кириченко 2 П. І. Когут ${ }^{3}$, В. І. Самуся ${ }^{2}$ Д. Л. Колосов ${ }^{2}$
1 - Сілезький технічний університет, м. Катовіце, Польща, e-mail: aleksander.sladkowski@polsl.pl

2 - Національний технічний університет „Дніпровська політехніка“, м. Дніпро, Україна, e-mail: vsamusya@ gmail.com; evolyuta@gmail.com

3 - Дніпровський національний університет імені Олеся Гончара, м. Дніпро, Україна, e-mail: p.kogut@i.ua

Мета. Розробка методичного забезпечення унікального способу насосного глибоководного гідропідйому (НГГ) для транспортування багатофазних потоків із твердою фракцією та інноваційних насосних установок для його реалізації у складних умовах великих глибин.

Методика. Теоретичні дослідження механізму багатофазних течій у проточній частині транспортного трубопроводу гідропідйому та конструкцій насосної установки, що транспортує важку гідросуміш з абразивною твердою фракцією для побудови адекватної моделі насосного глибоководного гідропідйому газованих рідин з великим газовмістом. Методика базується на логічній структурі досліджень багатофазного потоку в умовах великих градієнтів тиску й новому підході до розрахунку потужних гідропідйомів, що перекачують неврівноважені гетерогенні суміші, які стискаються та є нестисливими. Залежно від величини потоку десорбції і глибини гідропідйому визначають раціональну кількість насосних агрегатів і їх місце розташування. Розраховують витратні та енергетичні параметри процесу транспортування гідросуміші з використанням математичного й програмного забезпечення способу гідропідйому.

Результати. Запропонована експериментальна технологія для транспортування важких абразивних гірських мас в океанічних районах з великим газовмістом у морській воді. Ця технологія полягає в поєднанні інноваційного способу насосного гідропідйому твердого матеріалу у складі газованих рідин і оригінальної конструкції насосної установки та відрізняється поліпшеними експлуатаційними характеристиками. Розроблена нова детермінована модель нерівноважного багатофазного потоку в напірному трубопроводі значної протяжності та симуляційний програмний комплекс.

Наукова новизна. Розроблено унікальний НГГ, що транспортує гетерогенні суміші, який створено на основі прогресивних нерівноважних багатофазних моделей з урахуванням масообмінних процесів десорбції, що викликані значними градієнтами тиску.

Практична значимість. Запропоновані й запатентовані інноваційні конструкції насосних установок, які виключають переподрібнення твердих часток шляхом усунення взаємодії робочого колеса насоса з матеріалом, що транспортується.

Ключові слова: насос, трубопровід, робоче колесо, гідротранспорт, фаза, математична модель, гетерогенні суміші, конструкиія 


\section{Инновационные конструкции насосных глубоководных гидроподъемов на базе прогрессивных многофазных неравновесных моделей}

\author{
А. В. Сладковски ${ }^{1}$, Е.А. Кириченко ${ }^{2}$, П. И. Когут ${ }^{3}$, \\ В. И. Самуся ${ }^{2}$, Д. Л. Колосов ${ }^{2}$
}

1 - Силезский технический университет, г. Катовице, Польша, e-mail: aleksander.sladkowski@polsl.pl

2 - Национальный технический университет „Днепровская политехника“, г. Днепр, Украина, e-mail: vsamusya@ gmail.com; evolyuta@gmail.com

3 - Днепровский национальный университет имени Олеся Гончара, г. Днепр, Украина, e-mail: p.kogut@i.ua

Цель. Разработка методического обеспечения уникального способа насосного глубоководного гидроподъема (НГГ) для транспортирования многофазных потоков с твердой фракцией и инновационных насосных установок для его реализации в сложных условиях больших глубин.

Методика. Теоретические исследования механизма многофазных течений в проточной части транспортного трубопровода гидроподъема и конструкций насосной установки, транспортирующей тяжелую гидросмесь с абразивной твердой фракцией для построения адекватной модели насосного глубоководного гидроподъема газированных жидкостей с большим газосодержанием. Методика базируется на логической структуре исследований многофазного потока в условиях больших градиентов давления и новом подходе к расчету мощных гидроподъемов, перекачивающих сжимаемые и несжимаемые неравновесные гетерогенные смеси. В зависимости от величины десорбционного потока и глубины гидроподъема определяют рацио- нальное количество насосных агрегатов и их местоположение. Рассчитывают расходные и энергетические параметры процесса транспортирования гидросмеси с использованием математического и программного обеспечения способа гидроподъема.

Результаты. Предложена экспериментальная технология для транспортирования тяжелых абразивных горных масс в океанических районах с большим газосодержанием в морской воде. Данная технология заключается в сочетании инновационного способа насосного гидроподъема твердого материала в составе газированных жидкостей и оригинальной конструкции насосной установки и отличается улучшенными эксплуатационными характеристиками. Разработана новая детерминированная модель неравновесного многофазного потока в напорном трубопроводе значительной протяженности и симуляционный программный комплекс.

Научная новизна. Разработан уникальный НГГ, транспортирующий гетерогенные смеси, созданный на основе прогрессивных неравновесных многофазных моделей с учетом массообменных десорбционных процессов, вызванных значительными градиентами давления.

Практическая значимость. Предложены и запатентованы инновационные конструкции насосных установок, исключающие переизмельчение твердых частиц путем устранения взаимодействия рабочего колеса насоса с транспортирующимся материалом.

Ключевые слова: насос, трубопровод, рабочее колесо, гидротранспорт, фаза, математическая модель, гетерогенные смеси, конструкция

Рекомендовано до публікації докт. техн. наук B. А. Ропаєм. Дата надходження рукопису 06.04.18. 